
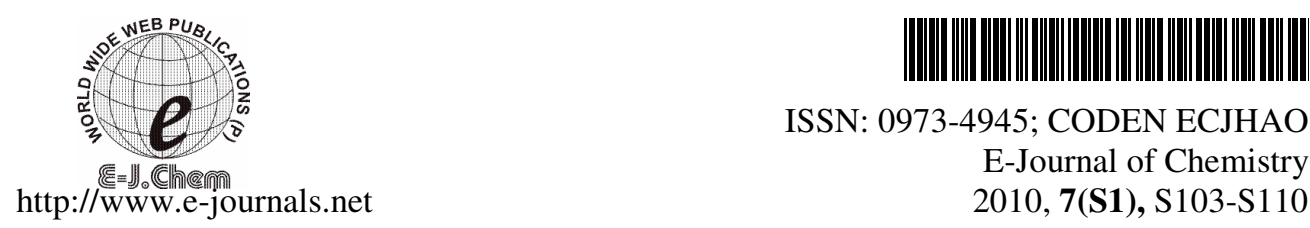

ISSN: 0973-4945; CODEN ECJHAO

E-Journal of Chemistry

2010, 7(S1), S103-S110

\title{
A New Ritodrine Selective Electrode and its Pharmaceutical Application
}

\author{
REDA AMMAR \\ Department of Chemistry \\ Faculty of Science, King Saud University, Riyadh, Saudi Arabia \\ dr_reda06@yahoo.com
}

Received 13 February 2010; Accepted 8 April 2010

\begin{abstract}
A novel ritodrine hydrochloride ion-selective PVC membrane electrode based on ion-pair complex of ritodrine-tetra phenyl borate was prepared with $d i-n$-butyl phosphate as a plasticizer. The influences of membrane composition, temperature, $\mathrm{pH}$ of the test solution and foreign ions on the electrode performance were investigated. The electrode showed a Nernstian response over a wide ritodrine concentration range $\left(1 \times 10^{-5}\right.$ $1 \times 10^{-2} \mathrm{M}$ ) with a slope of $59.33 \mathrm{mV}$ decade $^{-1}$ and was found to be very selective, precise and usable within the $\mathrm{pH}$ range 3-7.5. The standard electrode potentials, $E^{\circ}$, were determined at different temperatures and used to calculate the isothermal temperature coefficient $\left(\mathrm{d} E^{\circ} / \mathrm{d} T\right)$ of the electrode, which was 0.00075 . The electrode was successfully used for potentiometric determination of ritodrine hydrochloride both in pure solutions and in pharmaceutical preparations.
\end{abstract}

Keywords: Ritodrine hydrochloride, Ion-selective electrode, Pharmaceutical analysis.

\section{Introduction}

Ritodrine hydrochloride (RTH), chemically [1-(4- hydroxy phenyl)-2-[2-(4-hydroxy phenyl) ethyl amino] propanol-hydrochloride], is a selective $\beta_{2^{-}}$adrenergic agonist solely used as uterine relaxant. It decreases uterine contractility and is used to arrest premature labour and as an emergency means of alleviating foetal asphyxia during labour ${ }^{1,2}$. A review of literature revealed that several methods have been reported for the determination of ritodrine ${ }^{3-13}$. The chemical structure of ritodrine hydrochloride was depicted in Figure 1.

The aim of the present work, describes a sensitive and reasonably selective poly (vinyl chloride) membrane electrode based on the use of ritodrine - tetra phenyl borate as a novel electroactive material. The electrode exhibit useful analytical characteristics for the direct determination of ritodrine $\mathrm{HCl}$ in pure form and in pharmaceutical preparations. 
<smiles>Oc1ccc(CCNCC(O)c2ccc(O)cc2)cc1</smiles>

\section{Experimental}

Figure 1. Chemical structure of ritodrine $\mathrm{HCl}$.

All chemicals were of analytical grade and double distilled water was used throughout the experiments. Ritodrine hydrochloride, PVC of relative high molecular mass and tetrahydrofuran (THF) were obtained from Sigma -Aldrich, Sodium tetra phenyl borate (Na-TPB) and $d i$ - $n$-butyl phosphate (DBP) were obtained form Merck. The pharmaceutical preparations containing ritodrine hydrochloride (Yutopar ${ }^{\circledR}$ tablets10mgltablet or ampoules $10 \mathrm{mg} \backslash \mathrm{mL}$ ) were purchased from local drug stores.

Stock ritodrine hydrochloride solution $\left(1 \times 10^{-1} \mathrm{M}\right)$ was prepared daily by dissolving an appropriate amount of the drug in double distilled water. More dilute solutions were prepared by appropriate dilution. The stock solution and dilutions were kept in dark bottles in the refrigerator. To investigate the selectivity of the proposed electrode towards inorganic cations, sugars and amino acids $1 \times 10^{-2} \mathrm{M}$ salt solutions of each of the following ions were prepared: $\mathrm{Na}^{+}, \mathrm{K}^{+}, \mathrm{Li}^{+}, \mathrm{Pb}^{2+}, \mathrm{Mg}^{2+}, \mathrm{Co}^{2+}, \mathrm{Cr}^{3+}, \mathrm{Al}^{3+}$ and $\mathrm{Fe}^{3+}$. Also $1 \times 10^{-2} \mathrm{M}$ solutions of glucose, lactose, starch, glycine, aspargine and alanine were prepared.

\section{Preparation of the ion- pair}

The ritodrine tetra phenyl borate (RTH-TPB) ion-pair was prepared by mixing $50 \mathrm{~mL}$ of aliquots of $1 \times 10^{-2} \mathrm{M}$ RTH and sodium tetra phenyl borate. The resulting precipitate was filtered, washed thoroughly with double distilled water till chloride free (tested using $\mathrm{AgNO}_{3}$ solution) and dried at room temperature for at least 3 days. The chemical composition of the ion- pair as identified by elemental analysis was found to be 1:1 (RTH-TPB). Analysis: Calc. for $\left[\mathrm{C}_{17} \mathrm{H}_{22} \mathrm{NO}_{3}\right]\left[\mathrm{C}_{24} \mathrm{H}_{20} \mathrm{~B}\right]: \mathrm{C}, 81.05 ; \mathrm{H}, 6.97 ; \mathrm{N}, 2.31$. Found: $\mathrm{C}, 80.96 ; \mathrm{H}, 6.33 ; \mathrm{N}, 2.02$.

\section{Preparation of membrane}

The membrane was prepared by dissolving the required amounts of PVC, DBP and ion-pair of total weight $0.20 \mathrm{~g}$ in a $5 \mathrm{~cm}$ (diameter) Petri dish containing $5 \mathrm{~mL}$ THF, covered with a filter paper and the solvent was allowed to evaporate slowly at room temperature.

\section{The electrochemical system}

Potentiometric measurements were carried out with a Jenway $3010 \mathrm{pH}-$ meter. A Techne circulator thermostat, Model C-100, was used to control the temperature of the test solution. The electrochemical system is represented as follows: $\mathrm{Ag} / \mathrm{AgCl} /$ internal solution /membrane/test solution/KCl salt bridge//SCE. Where the internal solution is a mixture containing equal volumes of $1 \times 10^{-3} \mathrm{M}$ RTH and potassium chloride. Jenway 4330 conductivity meter was used for conductance measurements.

\section{Electrode Calibration}

Suitable increments of standard drug solution were add to $50 \mathrm{~mL}$ doubly distilled water so as to cover the concentration range from $1 \times 10^{-6}-1 \times 10^{-2} \mathrm{M}$. In this solution the sensor and reference electrode were immersed and the e.m.f values were recorded after each addition.

The values were plotted against the negative logarithm of drug concentration $\left(\mathrm{P}_{\mathrm{drug}}\right)$. The electrode was washed with double distilled water and dried between measurements. 


\section{Selectivity of the electrode}

Selectivity coefficients were determined by the separate solution method ${ }^{14}$, in which the following equation was applied.

$$
\log K_{R T H, B^{z+}}^{\text {pot. }}=\left(E_{2}-E_{1}\right) / S+\log [R T H]-\log \left[B^{z+}\right]^{1 / z+}
$$

Where $E_{1}$ and $E_{2}$ are the electrode potentials of solutions of the RTH and interfering cation, $\mathrm{B}^{\mathrm{z}}$, respectively (both of the same concentration) and $\mathrm{S}$ is the slope of the calibration graph.

\section{Potentiometric determination of $R T H$}

The standard addition method was applied ${ }^{15}$, in which a known incremental change is made through the addition of standard solution of the sample. This was achieved by adding known volumes of standard drug solution to $50 \mathrm{~mL}$ aliquot water containing various amount of the investigated drug in its pure state or pharmaceutical preparations (tablets or ampoules). The change in potentials was recorded for each increment and used to calculate the concentration of RTH sample solution using the following equation:

$$
C_{x}=C_{s}\left(\frac{V_{s}}{V_{s}+V_{x}}\right)\left(10^{n(\Delta E / s)}-\frac{V_{x}}{V_{s}+V_{x}}\right)^{-1}
$$

Where $\mathrm{C}_{\mathrm{x}}$ and $\mathrm{V}_{\mathrm{x}}$ are the concentration and volume of the unknown, respectively, $\mathrm{C}_{\mathrm{s}}$ and $\mathrm{V}_{\mathrm{s}}$ are the concentration and volume of the standard, respectively, $\mathrm{S}$ is the slope of the calibration graph and $\Delta \mathrm{E}$ is the change in potential due to the addition of the standards.

For the analysis of tablets, 20 tablets were accurately weighed and powdered in a mortar; then, the required amount from the tablet powder was taken as sample and dissolved in $10^{-2} \mathrm{M} \mathrm{HCl}$, the solution was completed to $50 \mathrm{~mL}$ with distilled water. As for ampoules, the content of 10 ampoules were mixed and the requisite volume was transferred to a $50 \mathrm{~mL}$ volumetric flask, the flask was completed to mark with double distilled water.

\section{Conductimetric determination of $R T H$}

A volume containing $10-90 \mathrm{mg}$ of RTH was transferred to a $50.0 \mathrm{~mL}$ volumetric flask and made up to the mark with double distilled water. The contents of the volumetric flask were transferred to a beaker and the conductivity cell was immersed. Then $10^{-2} \mathrm{M}$ NaTPB was added and the conductance was measured subsequent to each addition of the reagent solution after thorough stirring. The conductance reading after each addition was corrected for dilution ${ }^{16}$ by means of the following equation, assuming that conductivity was a linear function of dilution:

$$
\Omega_{\text {corr }}=\Omega_{\text {obs }}\left[v_{1}+v_{2} / v_{1}\right]
$$

Where $\Omega$ is electrolytic conductivity, $v_{l}$ is the initial volume and $v_{2}$ is the volume of the added reagent (corr. $=$ corrected and obs. $=$ observed). A graph of corrected conductivity $v s$. volume of the added titrant was constructed, and the end point was determined.

\section{Potentiometric titration of $R T H$}

Different weights of the RTH was transferred into a $100 \mathrm{~mL}$ beaker and diluted to $50 \mathrm{~mL}$ with double distilled water. The resulting solutions were titrated against $10^{-2} \mathrm{M} \mathrm{Na-TPB}$ using the investigated electrode as indicator electrode. The same method was applied for the determination of RTH in the pharmaceutical preparations. 


\section{Results and Discussion}

\section{Composition of the membrane}

Five different membrane compositions were investigated. They consist of 5.00, 6.00, 7.00, 8.00 and $10.00 \%$ of an ion pair and the ratio of the plasticizer to PVC was always 1:1. Electrode made by using membrane consisting of $7.00 \%$ ion pair show the nearest performance characteristic of the Nernstian behavior (slope $59.33 \mathrm{mV} \mathrm{decade}{ }^{-1}$ ), within the usable concentration range $1 \times 10^{-5}-1 \times 10^{-2} \mathrm{M}$ of ritodrine (Figure 2).

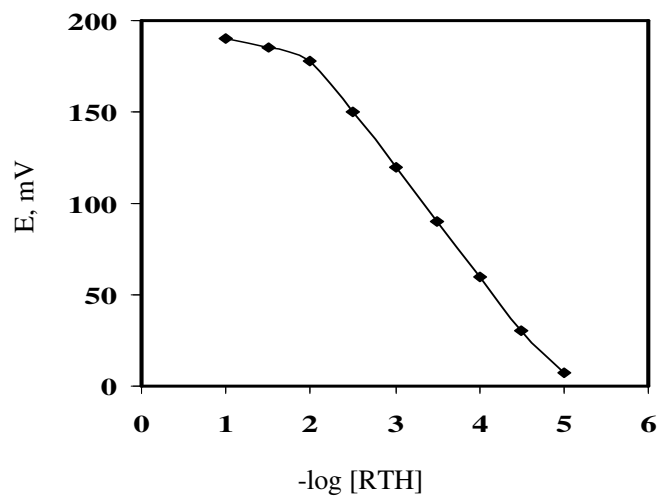

Figure 2. Typical calibration graph of RTH- selective electrode.

The slope increasing with increasing the composition may be attributed to the increase in the ion-exchange process at the solution-membrane interface reaching the near-Nernstian or Nernstian slope at the compositions $7.00 \%$. The response characteristics of the electrode under investigation were determined and results are summarized in Table 2.

Table 1. Composition of different RTH-TPB membranes and slopes of the corresponding calibration graphs at $25^{\circ} \mathrm{C}$.

\begin{tabular}{|c|c|c|c|c|}
\hline \multicolumn{3}{|c|}{ Composition \%(w\w) } & \multirow{2}{*}{$\begin{array}{c}\text { slope } \\
\mathrm{mV} \mathrm{decade}^{-1}\end{array}$} & \multirow[t]{2}{*}{ RSD } \\
\hline Ion Pair & DBP & PVC & & \\
\hline 5.00 & 47.50 & 47.50 & 477.05 & 0.82 \\
\hline 6.00 & 47.00 & 47.00 & 53.60 & 0.55 \\
\hline $7.00^{* *}$ & 46.50 & 46.50 & 59.33 & 0.92 \\
\hline 8.00 & 46.00 & 46.00 & 62.12 & 1.20 \\
\hline 10.00 & 45.00 & 45.50 & 65.02 & 0.96 \\
\hline
\end{tabular}

*Relative standard deviation(five determinations), "** Optimum composition.

Table 2. Critical response characteristics for RTH-selective electrode.

\begin{tabular}{ll}
\hline Parameter & Value \\
\hline Slope, $\mathrm{mVdecade}^{-1}$ & 59.33 \\
Correlation coefficient, $\mathrm{r}$ & 0.9989 \\
Linear range/M & $1 \times 10^{-2}-1 \times 10^{-5}$ \\
Working $\mathrm{pH}$ range $^{*}$ & $3-7.5$ \\
Response time & $\mathrm{s}$ \\
Life time/day & 15 \\
\hline
\end{tabular}

* Response time for $10^{-3} \mathrm{M}$ drug/sec. 
The response time of the electrode was tested for $1 \times 10^{-2}-1 \times 10^{-6} \mathrm{M}$ ritodrine hydrochloride solutions. This electrode exhibits a fast dynamic response of about $15 \mathrm{~s}$. When the concentration of drug solution was lower than $1 \times 10^{-5} \mathrm{M}$, the response time increased to $30 \mathrm{~s}$. The electrode was used for a period of 30 days without significant change in the electrode parameters.

\section{Effect of soaking}

The performance characteristics of the electrode were studied as a function of soaking time. For this purpose the electrode was soaked in $1 \times 10^{-3} \mathrm{M}$ of drug solution and the calibration graphs (pRTH $v s$. Eelec, mV) were plotted after 0.5, 1.0, 1.5, 2.0, 3.0, 4.0, 5.0 and 6 h. The optimum soaking time was found to be $0.5-2 \mathrm{~h}$, at which the slopes of the calibration curves were $57.0-59.0 \mathrm{mV}$ per concentration decade, at $25{ }^{\circ} \mathrm{C}$. Soaking for longer than $6 \mathrm{~h}$ is not recommended to avoid leaching, though very little, of the electro active species into the bathing solution. The electrode should be kept dry in an opaque closed vessel and stored in a refrigerator while not in use. The reproducibility of five repeated measurements on the same solution was $\pm 1 \mathrm{mV}$.

\section{Effect of $p H$}

The effect of $\mathrm{pH}$ of the ritodrine $\mathrm{HCl}$ solutions $\left(1 \times 10^{-3} \mathrm{M}, 1 \times 10^{-4} \mathrm{M}\right.$ and $\left.1 \times 10^{-5} \mathrm{M} \mathrm{RTH}\right)$ on the electrode potential was investigated. The solutions were acidified by the addition of very small volumes of $0.1 \mathrm{~N} \mathrm{HCl}$ acid then the $\mathrm{pH}$ value was increased gradually using $\mathrm{NaOH}(0.1$ or $1.0 \mathrm{M})$ for each $\mathrm{pH}$ value, the potential was recorded and thus the potential$\mathrm{pH}$ curves for three ritodrine $\mathrm{HCl}$ concentrations were constructed as shown in Figure 3.

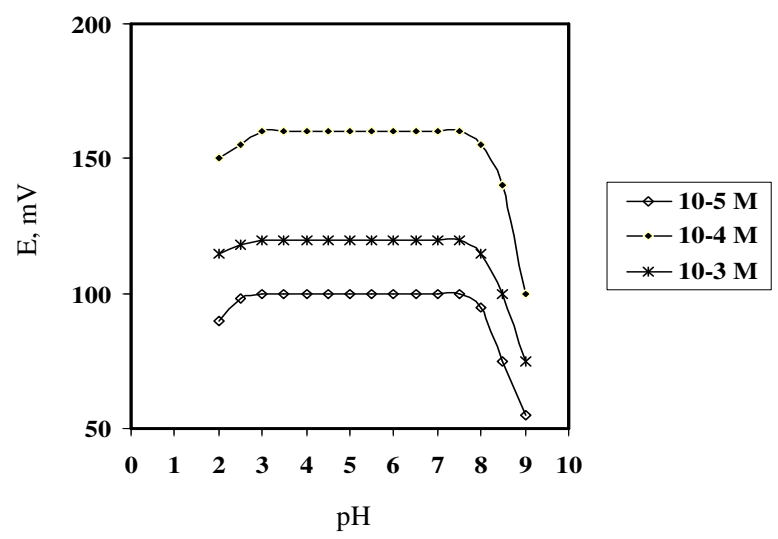

Figure 3. Effect of $\mathrm{pH}$ on the potential response of RTH-selective electrode for different concentrations.

The change in $\mathrm{pH}$ had a negligible effect in the $\mathrm{pH}$ range 3-7.5 and thus in this range the electrode can safely be used for ritodrine $\mathrm{HCl}$ determination. The decrease in the potential reading with $\mathrm{pH}$ above the mentioned range can be attributed to the formation of the free base of the drug and disappearance of the protonated species ${ }^{17,18}$.

\section{Conductimetric studies of pure solution of drug}

Conductance measurements have been used successfully in quantitative conductimetric titration of system in which the conductance of the solution varies before and after the equivalence point. The system under investigation showed a regular rise in conductance up to the equivalence point where a sudden change in the slope occurred. The results of the drug determination (Table 3) showed that good recoveries and low standard deviations were 
obtained. The optimum concentration ranges for RTH determination were $10.00-90.00 \mathrm{mg}$ with mean recovery value of 100.06 with coefficients of variation of $0.10-0.88$, at which sharp inflections and stable conductance readings were obtained.

Table 3. Conductimetric determination of ritodrine $\mathrm{HCl}$ in pure solution.

\begin{tabular}{ccc}
\hline \multicolumn{3}{c}{ Ritodrine HCl } \\
\hline Taken, mg & Recovery, \% & R.S.D., \% \\
\hline 10 & 100.10 & 0.10 \\
20 & 100.75 & 0.75 \\
60 & 100.84 & 0.83 \\
80 & 99.50 & 0.50 \\
90 & 99.11 & 0.88 \\
\hline
\end{tabular}

\section{Selectivity of the electrode}

The influence of some possible interfering inorganic cations, sugars and amino acids on the $\mathrm{RTH}$ - electrode was investigated. The resulting selectivity coefficients are summarized in Table 4. The selectivity coefficients revealed that the proposed electrode are highly selective. The inorganic cations did not interfere due to the differences in their ionic size, mobility and permeability. Also, the smaller the energy of hydration of the cation facilitated a greater response of the membrane. In the case of sugar and amino acid, the high selectivity is mainly attributed to the difference in polarity and lipophilic nature of their molecules relative to ritodrine hydrochloride.

Table 4. Selectivity coefficients of the RTH-selective electrode calculated by the separate solution method $\left(1 \times 10^{-3} \mathrm{M}\right.$ of both ritodrine and the interferent $)$ at $25^{\circ} \mathrm{C}$.

\begin{tabular}{cccc}
\hline Interferent & $K_{R T H, B^{Z+}}^{\text {pot }}$ & Interferent & $K_{R T H, B^{Z+}}^{\text {pot }}$ \\
\hline $\mathrm{Na}^{+}$ & $2.3 \times 10^{-3}$ & $\mathrm{Fe}^{3+}$ & $9.1 \times 10^{-4}$ \\
$\mathrm{~K}^{+}$ & $4.7 \times 10^{-3}$ & Glucose & $3.2 \times 10^{-2}$ \\
$\mathrm{Li}^{+}$ & $8.9 \times 10^{-3}$ & Lactose & $9.8 \times 10^{-2}$ \\
$\mathrm{~Pb}^{2+}$ & $3.5 \times 10^{-4}$ & Starch & $7.6 \times 10^{-2}$ \\
$\mathrm{Mg}^{2+}$ & $6.2 \times 10^{-2}$ & Glycine & $6.3 \times 10^{-4}$ \\
$\mathrm{Co}^{2+}$ & $5.1 \times 10^{-4}$ & Aspargine & $5.2 \times 10^{-4}$ \\
$\mathrm{Cr}^{3+}$ & $9.2 \times 10^{-3}$ & Alanine & $2.9 \times 10^{-4}$ \\
$\mathrm{Al}^{3+}$ & $5.7 \times 10^{-4}$ & & \\
\hline
\end{tabular}

\section{Effect of temperature of the test solution}

To study the effect of temperature, the electrode potential of $10^{-6}-10^{-2} \mathrm{M}$ drug solutions were determined in $15,20,25,30$ and $35{ }^{\circ} \mathrm{C}$ and the calibration graphs were constructed. The slope, usable concentration range and the standard electrode potentials $\left(E_{\text {elec. }}^{\circ}\right)$ obtained from the calibration plots as the intercepts at $-\log [\mathrm{RTH}]=0$ corresponding to each temperature is reported in Table 5. From the table, it is obvious that the electrode gave a good Nernstian response in the temperature range $15-25^{\circ} \mathrm{C}$, the slop of the electrode jump to a very high value $\left(100.02 \mathrm{mVdecade}^{-1}\right)$ at $35^{\circ} \mathrm{C}$ which may be attributed to decomposition

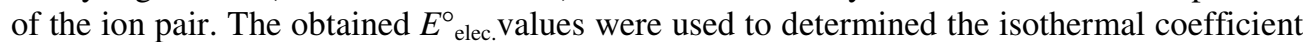
$\left(\mathrm{d} E^{\circ} / \mathrm{d} T\right)$ of the electrode using the following equation ${ }^{19}$.

$$
E^{\circ}=E_{25}^{\circ}+\left(\mathrm{d} E^{\circ} / \mathrm{d} T\right)(t-25)
$$


A plot of $E^{0} v s$. $(t-25)$ gave a straight line, the slope of which was taken as the isothermal temperature coefficient. It amounts to $0.00075 \mathrm{~V}$ per ${ }^{\circ} \mathrm{C}$, revealing a fairly good thermal stability of the electrode.

Table 5. Performance characteristics of RTH-selective electrode at different temperatures.

\begin{tabular}{cccc}
\hline Temperature, ${ }^{\circ} \mathrm{C}$ & $\begin{array}{c}\text { Slope } \\
\mathrm{mVdecade}^{-1}\end{array}$ & Usable range $\backslash \mathrm{M}$ & $E^{\circ}$ elec. $(\mathrm{mV})$ \\
\hline 15 & 54.20 & $1.53 \times 10^{-6}-2.20 \times 10^{-2}$ & -160.02 \\
20 & 58.55 & $1.60 \times 10^{-6}-1.32 \times 10^{-2}$ & -130.24 \\
25 & 60.21 & $1.78 \times 10^{-6}-2.78 \times 10^{-2}$ & -85.65 \\
30 & 79.22 & $1.89 \times 10^{-6}-3.64 \times 10^{-2}$ & -69.34 \\
35 & 100.02 & $4.60 \times 10^{-6}-1.64 \times 10^{-2}$ & -43.22 \\
\hline
\end{tabular}

\section{Analytical applications}

The investigated electrodes were found to be useful in the potentiometric determination of RTH in pure solutions and in the pharmaceutical preparations. The mean recovery and the relative standard deviation values are summarized in Table 6 . The data indicated that there was no interference from the excipients used in the formulations of the tablets and ampoules. The results of the pharmaceutical preparations were compared with the officinal method of United States Pharmacopoeia ${ }^{20}$ and are shown in Table 6. The results are in good agreement with those obtained from the officinal method. A statistical analysis of the results by Student's $t$ - and $F$-tests showed no significant difference in the accuracy and precision between the proposed and officinal methods

Table 6. Determination of ritodrine $\mathrm{HCl}$ in pure form and in pharmaceutical preparations using RTH-selective electrode.

\begin{tabular}{ccccccc}
\hline & \multicolumn{2}{c}{ Pure Solution } & \multicolumn{4}{c}{ pharmaceutical preparations } \\
\cline { 2 - 7 } & $\begin{array}{c}\text { Standard } \\
\text { addition }\end{array}$ & $\begin{array}{c}\text { Potentiometric } \\
\text { titration }\end{array}$ & $\begin{array}{c}\text { Standard } \\
\text { addition }\end{array}$ & $\begin{array}{c}\text { Potentiometric } \\
\text { titration }\end{array}$ & $\begin{array}{c}\text { Standard } \\
\text { addition }\end{array}$ & $\begin{array}{c}\text { Potentiometric } \\
\text { titration }\end{array}$ \\
\hline $\begin{array}{c}\text { Taken }{ }^{*} \\
\text { mg }\end{array}$ & 5 & 5 & 5 & 5 & 5 & 5 \\
& 10 & 10 & 15 & 15 & 15 & 15 \\
& 20 & 20 & 25 & 25 & 25 & 25 \\
Recovery, & 98.40 & 99.54 & 96.41 & 100.11 & 100.60 & 100.62 \\
$\%$ & 100.21 & 96.11 & 103.22 & 99.33 & 96.42 & 100.22 \\
& 96.50 & 100.23 & 101.13 & 100.20 & 99.50 & 104.21 \\
R.S.D. & & & & & & \\
$\%$ & 0.25 & 0.32 & 0.33 & 0.24 & 0.16 & 0.30 \\
& 0.26 & 0.28 & 0.36 & 0.27 & 0.19 & 0.24 \\
& 0.20 & 0.31 & 0.34 & 0.34 & 0.35 & 0.28 \\
& & & & & & \\
\hline
\end{tabular}

*Taken $\mathrm{mg}$ per $50 \mathrm{~mL}$. **Relative standard deviation (five determinations). 
Table 7. Statistical analysis of the results obtained for the determination of ritodrine $\mathrm{HCl}$ using RTH-selective in comparison with officinal method.

\begin{tabular}{llcccc}
\hline & \multicolumn{1}{c}{ Methodes } & \multicolumn{4}{c}{ Parameters } \\
\cline { 3 - 6 } & & Mean Recovery, \% & S.D. & $t$-value & $F$-value \\
\hline Yutopar & Standard addition & 100.25 & 0.30 & 2.03 & 2.11 \\
tablets & Potentiometric titration & 99.88 & 0.22 & 1.42 & 3.09 \\
& Officinal Method & 99.70 & 0.70 & & \\
Yutopar & Standard addition & 100.04 & 0.25 & 1.57 & 1.46 \\
ampoules & Potentiometric titration & 101.68 & 0.21 & 1.87 & 2.98 \\
& Officinal Method & 99.97 & 0.66 & & \\
\hline
\end{tabular}

\section{Conclusion}

"Tabulated value, 2.78. ${ }^{* *}$ Tabulated value, 6.39 .

The new ritodrine $\mathrm{HCl}$ selective $\mathrm{PVC}$ based membrane electrode exhibited the advantages of simple design and operation, reasonable selectivity, fast response and reproducibility. Further, the electrode can be used to determine ritodrine hydrochloride by direct potentiometry in pure form and in pharmaceutical preparations.

\section{References}

1. Hardman J G, Limbird L E and Gilman A G, Goodman and Gilman's The Pharmacological Basis of Therapeutics, $10^{\text {th }}$ Ed., McGraw-Hill, New York, 2001.

2. $\quad$ Razak O A, J Pharm Biomed Anal., 1998, 18, 359-365.

3. $\quad$ Sastry C S P and Chintalapati R, Indian Drugs, 2001, 38, 433-435.

4. van Staden J F, Beyene N W, Stefan R I and Aboul-Enein HY, Talanta, 2005, 68(5), 401-405.

5. Sastry C S P, Chintalapati R, Prasad AVS S and Sastry B S, Talanta, 2001, 53(5), 907-914.

6. Revanasiddappa H D and Manju B, Farmaco, 2001, 56, 615.

7. $\quad$ Bakry R S, El-Walily A F M and Belal S F, Mikrochim Acta., 1997, 127, 89-93.

8. Kuhnert P, Erhard P, Dixon A, Kuhnert B and Gross T, J Liq Chromatogr., 1983, 6, 2775.

9. Lin L S, Caritis S N and Wong L K, J Pharm Sci., 1984, 73, 131-133.

10. Gross T L, Kuhnert B R, Kuhnert P M, Rosen M G and Kazzi N J, Obstet Gynecol., 1985, 65, 793-797.

11. Bari V R, Dhorda U J and Sundaresan M, Indian Drugs, 1999, 39, 679-682.

12. Revanasiddappa H D and Manju B, J Anal Chem., 2003, 58, 775-777.

13. Gross A S, Brown K F, Baird-Lambert J A and Nation R L, J Chromatogr., 1987, 416, 400-408.

14. Moffat A C, Jackson J V, Moss M S and Widdop B, Pharmaceutical press, London, 1986, 794-795.

15. Baumann E, Anal Chim Acta., 1980, 42, 127.

16. Lingane J J, Electroanalytical Chemistry, 2 Ed., Interscience, Newyork, 1958, 90.

17. Shoukry A F, Issa Y M, Rizk M S and Abdel Aal M M, Electroanal., 1994, 6, 914-917.

18. Shoukry A F, Rizk M S, Abdel-Fattah H M, Issa Y M and Atia E M, J Chem Technol Biotechnol., 1994, 60, 217.

19. Antropov L I, Theoretical Electrochemistry, Mir Publishers, Moscow, 1972, p. 378.

20. United States Pharmacopoeia Rockville, 2000, 24, 1493. 


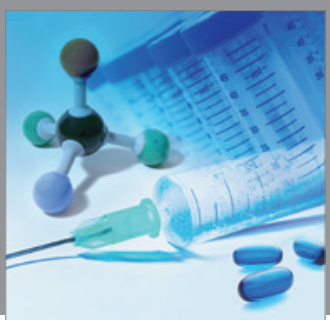

International Journal of

Medicinal Chemistry

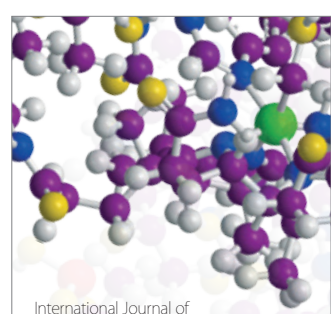

Carbohydrate Chemistry

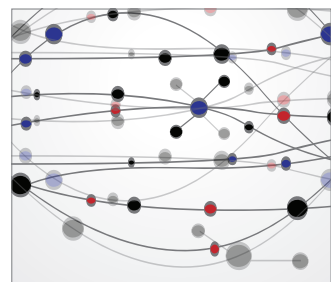

The Scientific World Journal
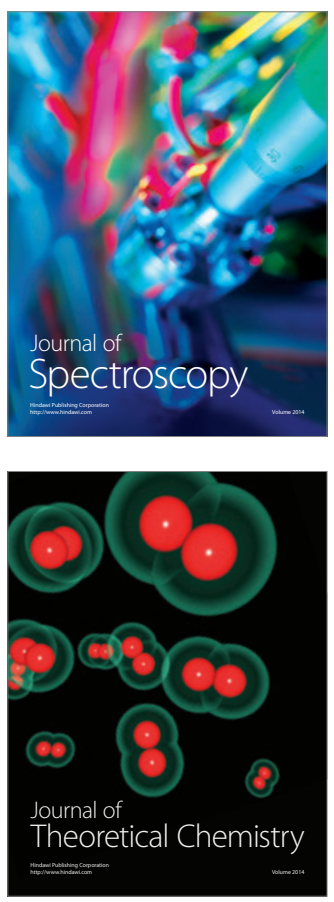
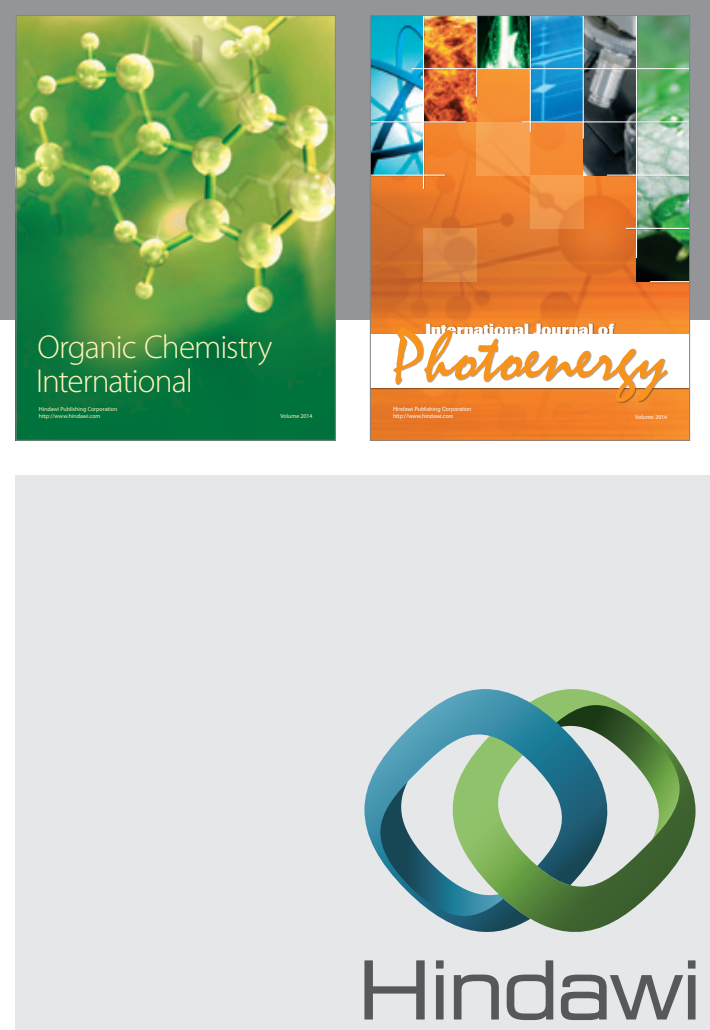

Submit your manuscripts at

http://www.hindawi.com
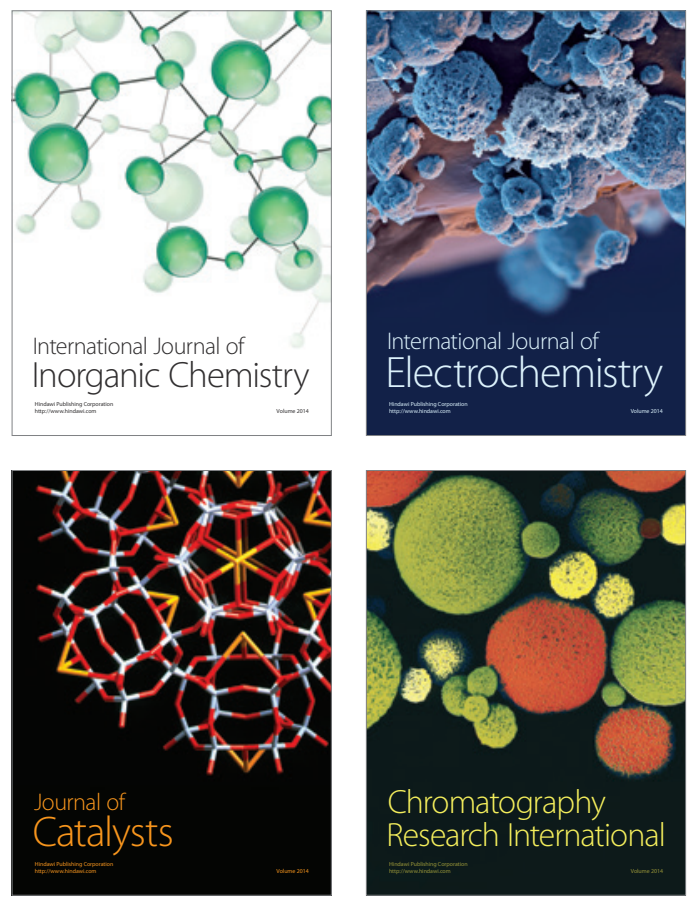
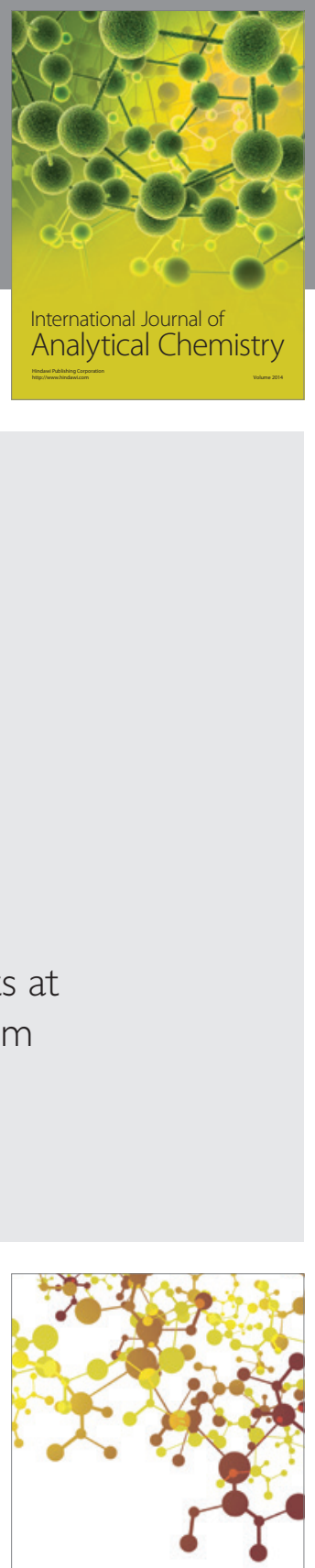

Journal of

Applied Chemistry
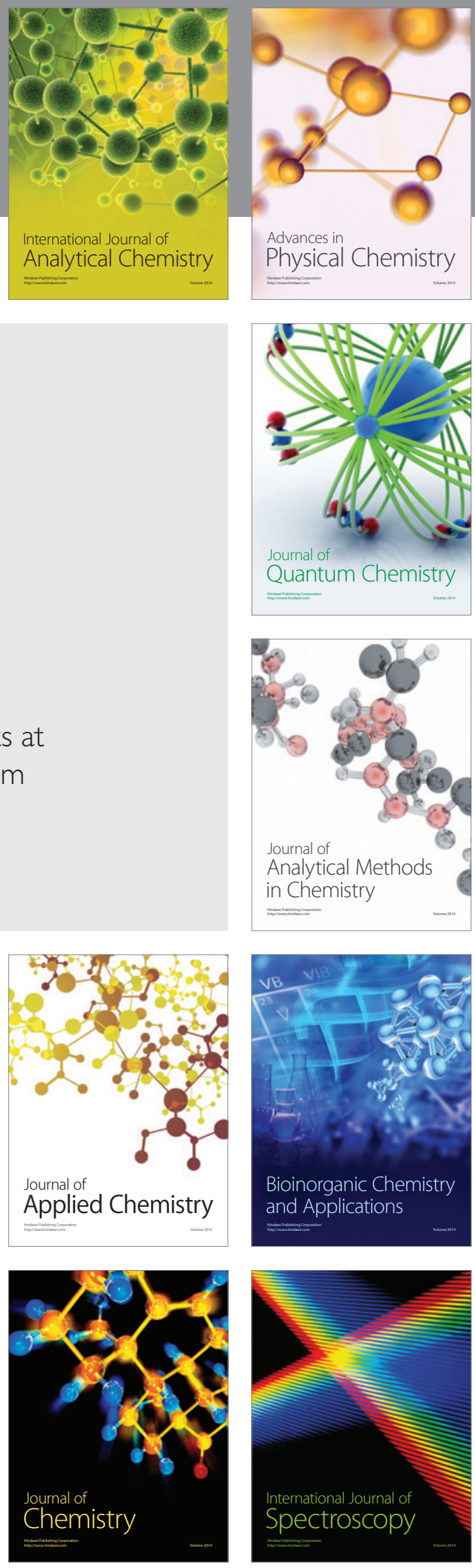